\title{
THE ANALYSIS OF COMPETITIVENESS MANAGEMENT SYSTEM OF FOOD ENTERPRISES IN THE DIFFERENT DISTRIBUTION CHANNELS ON THE EXAMPLE OF UKRAINE
}

\author{
Kostiantyn Bereznytskyi, Yulia Kalyuzhnaya, Natalia Protsuik \\ Poltava State Agrarian Academy, Ukraine \\ Joanna Nowakowska-Grunt \\ Czestochowa University of Technology, Poland
}

\begin{abstract}
The article describes the specifics of the concept of competitiveness and its management at food enterprises as well as prerequisites for the regional food associations' formation as a means of improving the industry competitiveness.
\end{abstract}

Keywords: competitiveness, regional associations,food industry, agro-industrial complex, strategic management, domestic and foreign distribution channels

DOI: $10.17512 /$ znpcz.2016.1.04

\section{The problem statement in general and its connection with important scientific and practical tasks}

The financial crisis makes food industry enterprises think about increasing their competitiveness.

The intensive growth of biotechnologies, increased production of computers and software, the development of chemical and pharmaceutical industries, and a number of other innovative technologies have led to a substantial progress in traditional industries, including food products' complex.

According to its technological and economic contents the food industry is a field of production which is closely connected with agriculture. So, it is natural that crop failures, market price fluctuations on raw materials lead to fluctuations in supply and demand for certain products. The most important factor of increasing food industry efficiency is a good management system, which is connected with territorial associations of producers. These innovative regional associations might be a guarantee of strengthening competitiveness in the national and foreign markets. They might have the opportunity to reduce their transaction costs, thanks to joint research, technological, and economic cooperation of its members. The serious problem concerning enterprises' competitiveness is the choice of the distribution channel, as an important element in the activities of enterprises and their groups. In many cases, the choice determines the appropriate distribution channel to achieve success of the enterprises in the market, 
especially concerning the efficiency of logistics operations, and satisfy the demand of final consumers, as well as ensure the availability of products on the international market.

\section{The analysis of recent studies and publications, which discuss the problem}

The theory of competitiveness has been studied by such foreign and Ukrainian scientists as M. Porter, I. Ansoff, A. Gradov, V. Dykan, I. Ivanov, I. Herchikov, A. Mazaraki, N. Ushakova, S. Lytvynenko, I. Smolin, I. Balabanova, O. Shishkova, and others (Gorynia, Nowak, Trąpczyński, Wolniak, 2013, pp.184 216; Romanowska, Gierszewska 2009; Nogalski, Waśniewski, Dryl 2014, pp. 279-290; Kościelniak 2006, pp. 61-63; Nowodziński 2011, pp. 179-190;SkowronGrabowska 2006, pp.77-82; Grabowska 2014, pp. 21-31).

\section{The problem statement}

The aim of the study is to analyze competitiveness management system of the food enterprises in the domestic and foreign markets.

\section{The results}

The problems of competitiveness have been studied by many scientists and economists, among them are: M. Albert, I. Blank, A. Gradov, M. Meskon, R. Fatkhutdinov, F. Hedouri, V. Shinkarenko, D. Yudanov, and others.

M. Meskon, M.Albert and F. Hedouri note that a competitive enterprise is the enterprise which has a strong competence, so it functions better than its competitors, and competitiveness allows to attract consumers (Meskon, Al'bert, Khedoury 1998, p. 800).

I. Blank defines competitiveness as the evaluation system of the company's economic activities, affecting the results of the competition with other companies in the consumer market (Blank 1997, p. 408).

A. Yudanov defines competitiveness as the ability of companies to produce and sell competitive products. The author notes that the company's competitiveness depends on its overall activities' efficiency and the effective use of enterprise's resources (Юданов 1998).

A. Gradov interprets the term "competitiveness" as the enterprise's comparative advantage in relation to other enterprises of the given branch in the country and abroad (Экономическая стратегия фирмы 2000, p. 588).

Competition is an integral part of a developed market. So there is an urgent need to study this phenomenon, its level and intensity, forces and market opportunities of the strongest competitors, the prospects of competition in the selected food industry markets.

The Law of Ukraine "About the Protection of Economic Competition" defines competition as "a contest between economic subjects in order to obtain benefits through their own achievements over other entities. As a result, consumers, 
businesses are able to choose among several sellers, while a separate entity cannot determine the conditions of circulating goods on the market" (Закон України 2001). It should be noted that the Law does not regulate the concept of "competitiveness", the Law also does not refer to the methodology of evaluating the competitiveness of businesses.

The competitiveness in the food industry is characterized by the level of performing specific functions, and depends on the efficiency of its functioning, which is measured not only by traditional criteria, but according to the industry peculiarities, the degree of the vitality and dynamism of the industry or its complexes at different levels of economic development in the regions, countries or the world on the whole.

Food industry is a very important economic sector of our country; this is explained by its share in the total production volume, export potential, and tax revenues which it provides. In 2014, the food industry occupied the second place in the sales volume; its share was $17 \%$, including drinks and tobacco.

The highest rate of decline is typical for the production of meat and dairy products, butter, cheese, flour, bakery products (see table 1).

According to the State Statistics Service of Ukraine, the profitability of food industry is quite low. As a result, the number of food enterprises and therefore the number of employees are constantly decreasing.

Table 1. The dynamics of the production volumes of the major Ukrainian food products during the period from 2009 to 2014

\begin{tabular}{|l|c|c|c|c|c|c|}
\hline & $\mathbf{2 0 0 9}$ & $\mathbf{2 0 1 0}$ & $\mathbf{2 0 1 1}$ & $\mathbf{2 0 1 2}$ & $\mathbf{2 0 1 3}$ & $\mathbf{2 0 1 4}$ \\
\hline $\begin{array}{l}\text { The production of meat and } \\
\text { meat products, thousand } \\
\text { tons }\end{array}$ & $1,501.8$ & $1,442.8$ & $1,352.4$ & $1,450.8$ & $1,439.7$ & $1,268.5$ \\
\hline $\begin{array}{l}\text { Processing and canning of } \\
\text { fruits and vegetables, } \\
\text { thousand tons }\end{array}$ & $1,199.7$ & $1,151.6$ & 919.6 & 924.2 & 851.2 & 834.5 \\
\hline $\begin{array}{l}\text { The production of oils and } \\
\text { fats, thousand tons }\end{array}$ & 2,545 & 2,183 & 3,149 & 3,393 & $3,529.2$ & 1,385 \\
\hline $\begin{array}{l}\text { The production of dairy } \\
\text { products and ice-cream, } \\
\text { thousand tons }\end{array}$ & 1,932 & $1,852.9$ & $1,734.6$ & 1,730 & $1,691.1$ & $1,753.1$ \\
\hline $\begin{array}{l}\text { The production of milling } \\
\text { and cereals processing } \\
\text { industry products, starch } \\
\text { etc., thousand tons }\end{array}$ & 3,226 & 3,393 & 3,131 & 2,972 & $2,569.1$ & 2,856 \\
\hline $\begin{array}{l}\text { Manufacturing of other } \\
\text { food products, thousand } \\
\text { tons }\end{array}$ & 4,951 & 4,631 & 4,146 & 4,699 & 5,326 & 3,589 \\
\hline $\begin{array}{l}\text { The production of drinks, } \\
\text { mln.dal }\end{array}$ & 774.9 & 745.9 & 666.9 & 687.9 & 644.3 & 548.6 \\
\hline $\begin{array}{l}\text { The production of } \\
\text { cigarettes, billion pieces }\end{array}$ & 129 & 130 & 114 & 103 & 95.5 & 126 \\
\hline
\end{tabular}

Source: http://www.ukrstat.gov.ua/ 
Further the geographical structure of production in the food industry will be characterized.

Ivano-Frankivsk region has the highest increase rate in food production. $(110,79 \%)$, it is by $10,79 \%$ more than the average indicators in Ukraine. Such regions as Cherkasy (809\%), Lviv (6,87\%), Zaporizhzhia (6,68\%), Kirovohrad $(5,69 \%)$, Poltava $(3,24 \%)$, Volyn $(2,84 \%)$, Mykolaiiv (1,65\%), Kyiv $(0,44 \%)$, Zhytomyr $(0,36 \%)$, Vinnytsia $(0,12)$ also have higher than the average rate of food industry development. Dnipropetrovsk (99,92\%), Khmelnytsky (99,86\%), Kherson $(99,82 \%)$, Ternopil $(99,36 \%)$, Rivne $(99,35 \%)$, Chernihiv $(99,03 \%)$ regions show almost the average rate. The biggest decline in food production is observed in Zakarpattia $(93,31 \%)$ and Odesa $(93,45 \%)$ regions.

According to advance regional coefficient, the regions can be devided into three groups (table 2).

Table 2. The grouping of the regions according to the food industry development in Ukraine

\begin{tabular}{|l|l|l|}
\hline \multicolumn{1}{|c|}{ Group } & $\begin{array}{c}\text { Advance regional } \\
\text { coefficient }\end{array}$ & \multicolumn{1}{c|}{ Regions } \\
\hline $\begin{array}{l}\text { Regions of fast } \\
\text { development }\end{array}$ & $101.65-110.79$ & $\begin{array}{l}\text { Ivano-Frankivsk, Kirovohrad, Cherkasy, Lviv, } \\
\text { Zaporizhzhia, Poltava, Volyn, Mykolaiv }\end{array}$ \\
\hline $\begin{array}{l}\text { Regions of medium } \\
\text { development }\end{array}$ & $99.03-100.44$ & $\begin{array}{l}\text { Kyiv, Zhytomyr, Vinnytsia, Dnipropetrovsk, } \\
\text { Khmelnytskyi, Kherson, Ternopil, Rivne, } \\
\text { Chernyhiv }\end{array}$ \\
\hline $\begin{array}{l}\text { Regions of slow } \\
\text { development }\end{array}$ & $93.31-98.04$ & $\begin{array}{l}\text { Chernyhiv, Kharkiv, Sumy, Odesa and } \\
\text { Zakarpattia }\end{array}$ \\
\hline
\end{tabular}

Source: own elaboration.

This table shows the regions with effective competitiveness management at food enterprises and the regions which are characterized by low the developed food industry.

Thus, a regional approach can be considered as an effective way of characterizing the development of the regional food industry, as a new tool for improving regional competitiveness management, based on effective use of agroindustrial, scientific, technological, and innovative regional policy. The regional economic strategy of the food industry development, should be aimed at stimulating the development of the above mentioned relations, and, thus, creating the competitive food industry.

The main task of the state strategy concerning the regional associations' development is to create the conditions for their effective work. Regional authorities should stimulate innovative and investing activities of food enterprises in order to manufacture competitive products in the region, to create innovative regional associations and the regional innovation and investment system in the food production sector of agro-industrial complex.

The term "regional association" as a peculiar and independent phenomenon in the economy appeared during the studying of geographically localized groups and companies' associations engaged in certain kinds of economic activities. Alfred 
Marshall (Маршалл 1993) studied the peculiarities of the industrial regions and noted that a lot of specialized companies were concentrated in such regions. But $\mathrm{M}$. Porter was the first who noted the benefits of competitive advantages of such companies. In his theory of national and local competitiveness he (Портер 2002, p. 49) determined that the most competitive multinational companies are not located haphazardly in various countries, but tend to be concentrated in one country or even in one region of the country. It is explained by the positive influence of competitive companies on the close surroundings: suppliers, customers, competitors, and the success of the surroundings influence the further growth of the company's competitiveness. Later on, M. Porter gave the following definition: "An industrial group is a group of close, geographically interdependent companies and related organizations that operate together in the same business, and complement each other" (Портер 1993, p. 896).

S. Sokolenko believes that "regional associations in Ukraine provide a unique basis for the innovative activities, increase productivity and profitability of the small and medium enterprises. These associations are a real "child" of globalization, they help to increase the role of the regions, to attract foreign investments, to teach a wide range of entrepreneurs, develop small and medium enterprises, to increase companies' flexibility and mobility, to create a wide range of networks. At the same time, regional associations are the link between business, government, and research institutions in developing competitive advantages within the city, region, province, state, country and even on the international level" (Соколенко 2007, p. 21).

At present, regional processing production complexes should become the driving force in developing the food industry. Various investigations show that the increasing level of economic freedom and independence of the regional processing businesses have a significant impact not only on social and economic regional development (progressive and regressive), but also on the factors and instruments ensuring their competitiveness and socio-economic stability. So, the competitive advantages of these associations can be emphasized.

Firstly, regional innovation associations have a stable system of propagating new technologies, knowledge, products, the so-called technological network which is based on the common scientific basis.

Secondly, regional food industry associations have additional competitive advantages thanks to the possibility of performing internal specialization and standardization, minimization of innovation costs.

Thirdly, innovative associations include flexible small businesses, which allow to form innovative places for the economic growth in the region.

Fourthly, regional innovation associations are extremely important for the small business development, because they provide a high degree of specialization in servicing specific business niches, provide facilitated access to industrial enterprise's capital, an active exchange of ideas takes place, the knowledge from experts to entrepreneurs is spread.

Each separate food enterprise interacts with the regional agrarian innovative association to develop more effective investment projects and financial mechanisms of their implementation. Compared to a single enterprise or 
agricultural holding, the regional association has a great potential to be included in the regional and other programs, to receive preferential loans, to lease equipment. Therefore, regional associations have more possibilities for innovative development, for increasing their competitiveness, entering inter-regional and international markets, providing guaranteed purchasing of agricultural products, for the state support on the basis of state and private partnership.

These associations are mostly experimental in Ukraine, and in general, this practice is not widespread. However, there are significant changes now: Ukraine's joining the WTO, and accordingly, opening the borders for foreign companies; the economic crisis which has significantly weakened the Ukrainian producers, lead to the increased competition between national and international producers. So, in our opinion, the creation of regional associations is the most effective way to protect national food producers. Regional associations are locally and hierarchically integrated companies, financial and business structures that provide high price, innovative and technological competition of manufactured products (Kalinichenko, Minkova, Kalinichenko 2015, pp. 68-75).

The model of the regional association can be represented as follows (figure 1). This type of association is competitive both in the domestic and foreign markets.

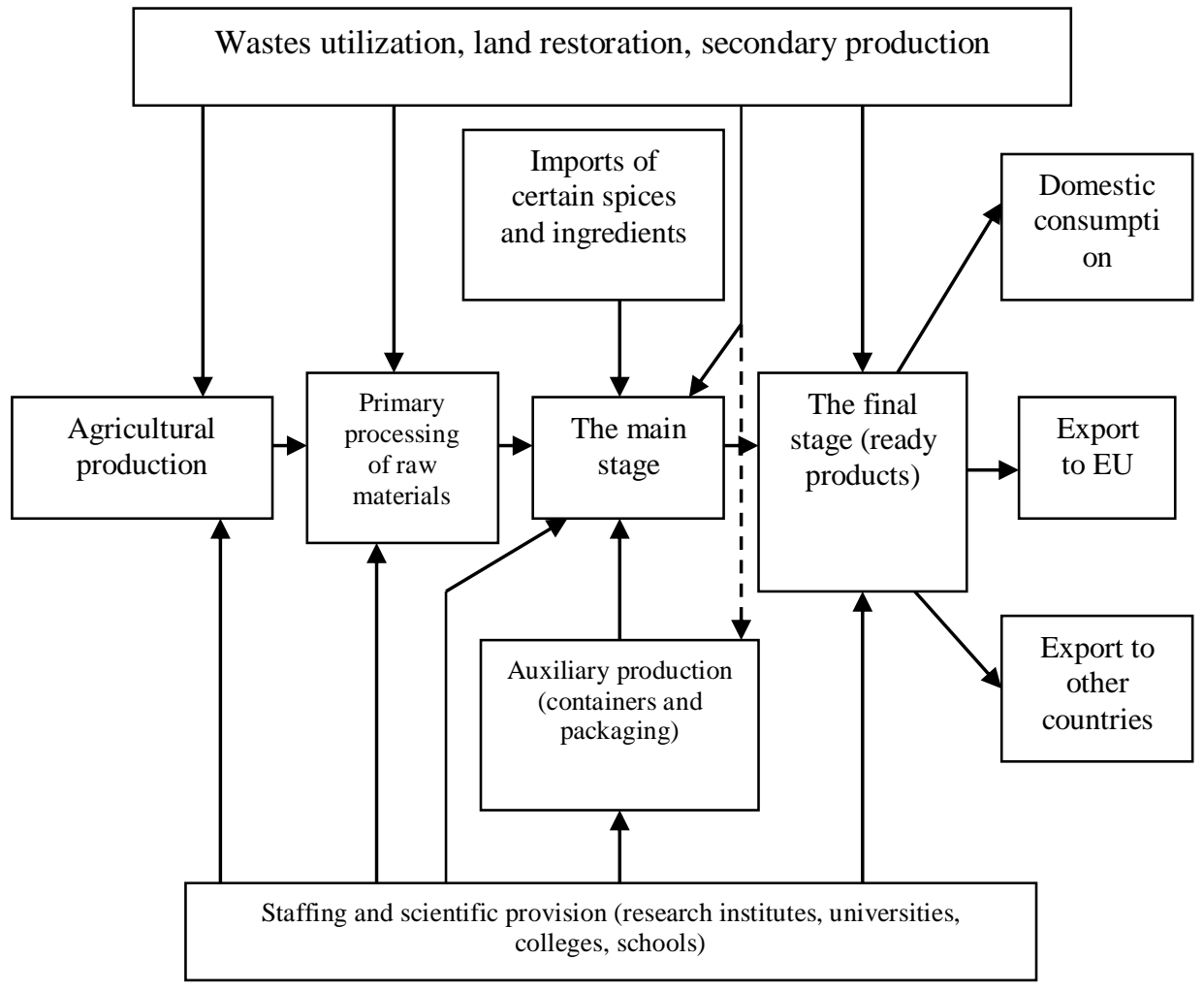

Figure 1. The model of the regional food association

Source: Own elaboration. 
As you can see, the given model is more vertically integrated, compared to the typical model of production organization, and it also includes a number of auxiliary industries (additives, packaging).

From the point of view of processing and logistics activities it seems important to integrate all the elements that affect the physical flow of goods and information. The using of logistics management in coordinating activities is also significant: it results in the decrease of logistics costs. This is particularly important in the context of high competitiveness that exists in the international market of food products. So, the goods produced in Ukraine must be competitive concerning low-cost production, packaging, distribution, etc. ( Brzozowska, Bubel 2014, pp. 27-30.19].

Let us consider the problem of long-term goals for ensuring the competitiveness of food industry enterprises.

It is proposed to list the priority of strategic goals in accordance with the forecasted state of the environment being mainly oriented at its state closer to the end of the strategic planning period. Significant changes of the environment may require corresponding corrections of the current target priorities envisaged by the strategic plan in order to prevent the termination of the food enterprise functioning as an independent production and operation unit. The process of forming the evaluation of the food enterprise activities' efficiency based on setting the priority goals, as it is seen by the author, is presented in figure 2 .

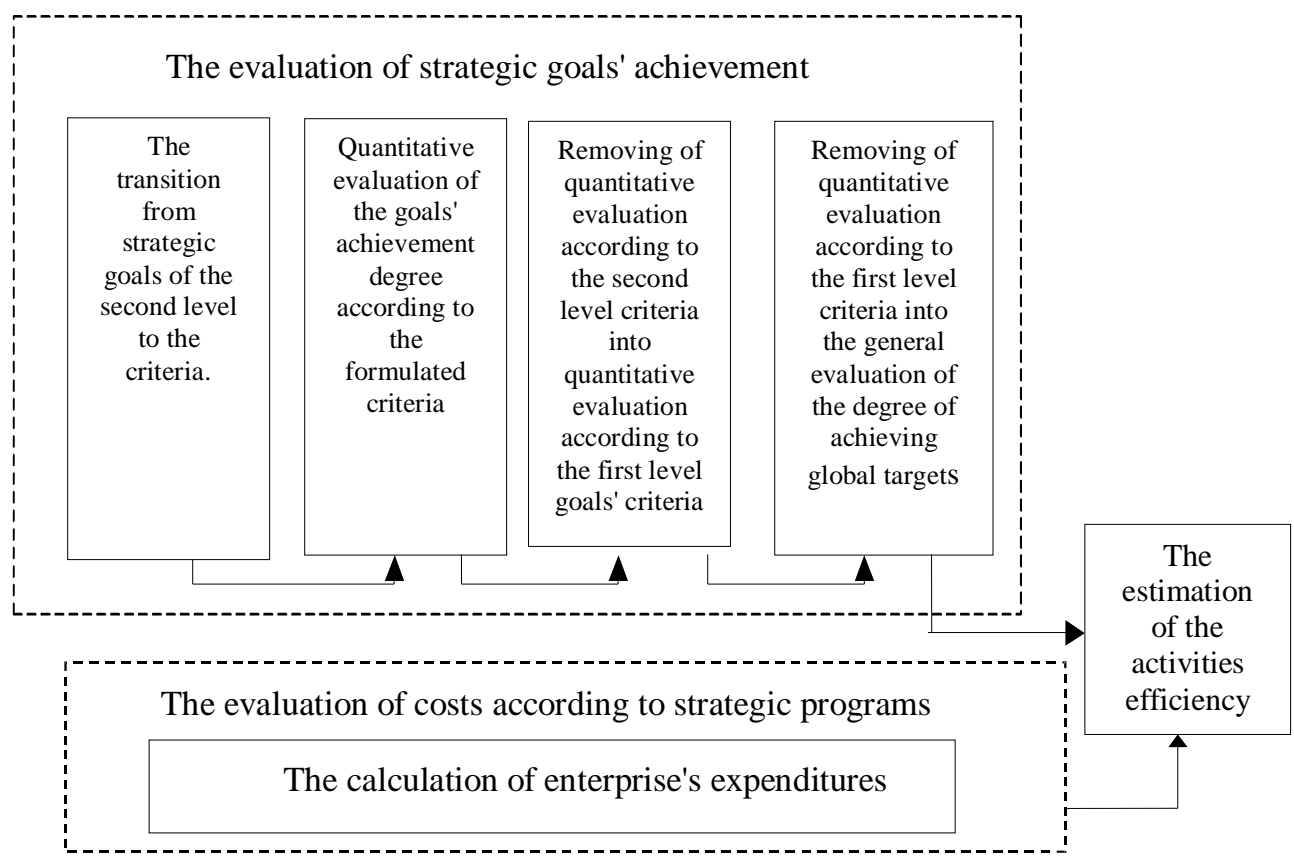

Figure 2. The scheme for the evaluation of the efficiency of the food enterprise's activities based on defining the priority of its goals

Source: (Ггнатьєва 2004, pp. 135-14020]. 
The method of establishing the goals' priority of the food enterprise with the aim of further using evaluation results to make the analysis of the enterprise's activities on the whole has been suggested within the system concept. The geometrical method of the system state diagnostics is its basis. The evaluation of the environment should be used for the analysis of the enterprise's competitive advantages. According to I. Ignatiev (Ігнатьєва 2005, pp. 1129-1140) the evaluation of competitive advantages of the enterprise can be represented by the following scheme (figure 3).

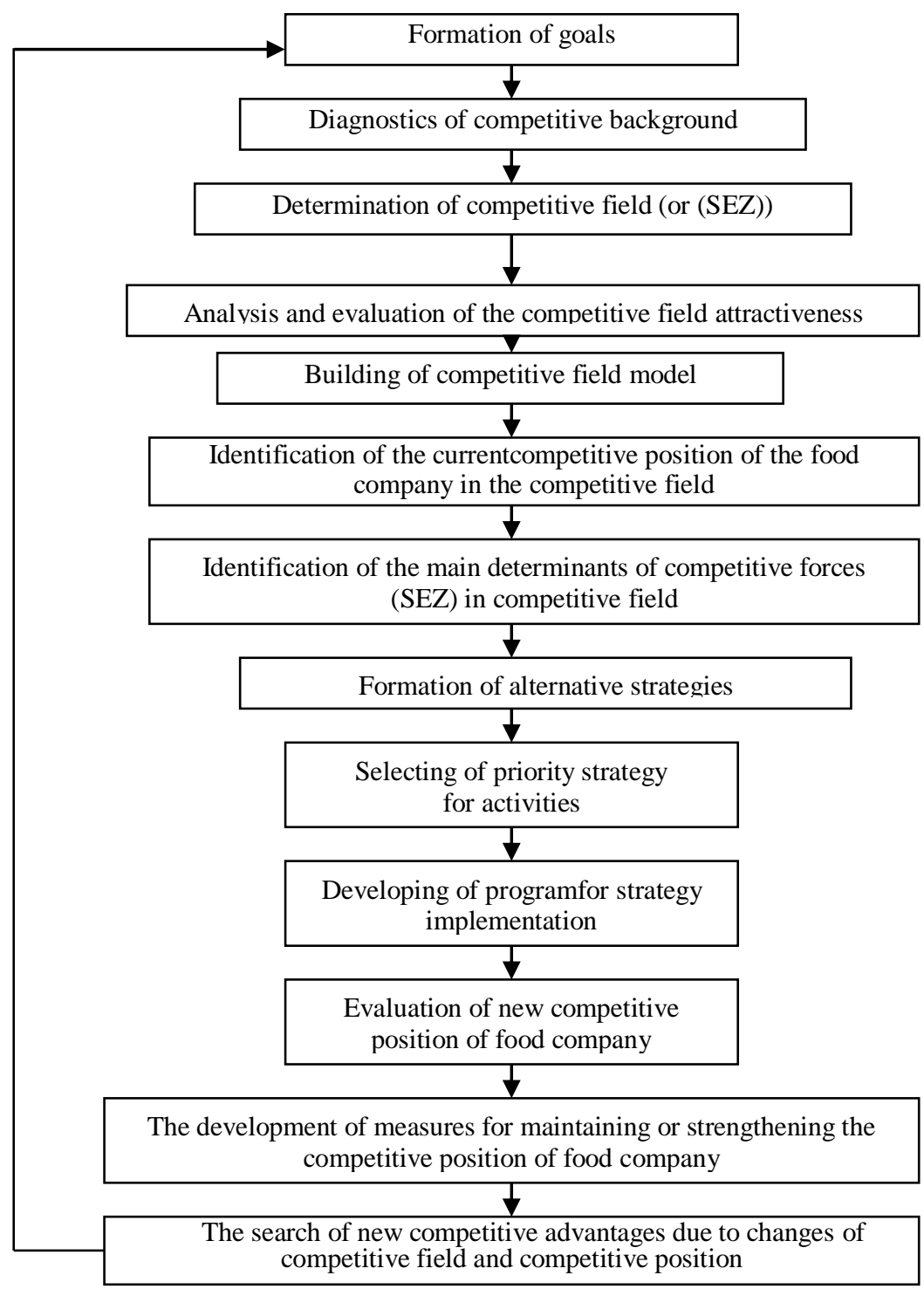

Figure 3. The scheme for evaluation methods of food enterprisecompetitiveness

Source: Own elaboration. 
The author states that competitive advantages are a quite complex multi-level concept, so their analysis and evaluation should be closely associated with the competitive background and competitive field, especially its level. In separating the competitive field, the three levels of competitive relations were taken into account: micro-level (specific types of the company's products); meso-level (industries, corporated enterprises); macro-level (the economy of the country).

It should be noted that such structuring of competition subjects has allowed to give a more accurate characteristics of these elements' composition and identify their relationship. It has also helped to prove the effectiveness of the approaches in evaluating the food enterprise position in accordance with the competitive field, which opens additional possibilities for defining the strategic directions of increasing competitiveness on each level. Such structuring is the more important, the more complex the competitive field and the relationship between the subjects of competition are.

Thus, we have come to the conclusion that the defining of a competitive background is not only the revealing of the factors which are not connected with the market directly, but also determining the importance of these factors for the enterprise's activities.

The process of competitive background analyzing is a complex and timeconsuming procedure, and its final results are the following:

1) the identification of relatively important factors, which could affect the development of the industry and changes in the market, and the force of each factor of influence;

2) the creation of the possible way of development of the competitive background components within the specified period of time;

3) the identification of main competitive background advantages that are the main components of the economic system functioning (global, national, regional).

Studying the attractiveness of the competitive field is the following very important element in the evaluation of the enterprise's competitive position. It is necessary to establish a strategic economic zone (SEZ) of the food enterprise, which includes three stages: focusing (distinguishing the evaluation indicators), verification (distinguishing possible/threats); conclusions (choosing the category of the market attractiveness).

Successful selection of the SEZ will provide:

- more complete evaluation of the attractiveness and viability of the SEZ establishing;

- a clear definition of the enterprise's current competitive position;

- the right choice of the enterprise'scompetitive strategies to achieve more stable and strong positions in the competitive field..

\section{The conclusions}

Each food enterprise must develop its own system of competitiveness management taking into account its specifics and peculiarities. All the components of the food enterprise competitive potential - modern technology, equipment, 
trained staff, and other resources, which are used for company's functioning and its strategic development in a competitive environment - are to be the objects of management. To increase the competitive position of the food enterprise, it is necessary to satisfy consumers' demands completely; to develop infrastructure of supply and marketing; to provide proper scientific support of the branch.

Justifying the necessity of the territorial organizing of the food industry, detecting and taking into account its components help to form the scientific basis for solving the problems of optimal location of food enterprises. It is also important to keep the balance of raw materials' base and preserve the enterprises' capacity, to find the reserves for the increase of production effectiveness, to evaluate regional potential opportunities in food production, to form the reserve fund and the state's export potential, to forecast the development of food industry and its branches.

However, the technological level of the Ukrainian agro-industrial complex on the whole and its food industry is very low. So, the creation of regional associations may be a good solution in solving the problem.

The manufacturing of competitive products is impossible without scientific provision of the branch. To develop science in the food industry it is necessary to accumulate the finance of enterprises. This will help to conduct the general research work: the revision of regulation and technical documentation, the development of new competitive products, the creation of advanced technologies and equipment, etc.

Thus, the regional approach can be viewed as an effective way to develop regional food industry, as a new tool for improving regional competitiveness management, based on the effective use of agro-industrial, scientific, technological, and innovative regional policy.

After evaluating the state and prospects of the Ukrainian food industry enterprises, the following ways to improve their competitiveness in the national and international markets have been suggested: the evaluation of consumer products' preferences; constant updating of fixed assets; the development of innovations in the food industry; choosing the effective sales channels; forming the promotion strategy in the Ukrainian and foreign markets, and so on.

\section{References}

1. Blank Y.A., Torhovyi menedzhment [Trade management]. - K.: Ukraynsko-fynskyy instytut menedzhmenta y byznesa, 1997, p. 408.

2. Brzozowska A., Bubel D., Communication Management in the aspect of Food Industry, Proceedings of the International Forum on Agri-Food Logistics. Ind Domestic Scientific Conference AGROLOGISTYKA 2014. Efficient Logistics as a Chance of Efficient Consumer Response in the Agri-Food Sector. Poznan, Poland, September 9-13th, 2014, pp. 27-30.

3. Gorynia M., Nowak J., Trąpczyński P., Wolniak R., Internationalization of Polish Firms via Foreign Direct Investment: A Multiple-Case-Study Approach. DOI 10.1057/9781137369413_8, ed. M. Marinov, S. Marinova Successes and Challenges of Emerging Economy Multinationals Palgrave Macmillan, 2013, pp.184 - 216, DOI 10.1057/9781137369413

4. Grabowska M., Aspects of Relationships in Interorganizational Enterprises, [in:] Managing Organizations in Changing Environment. Models - Concepts - Mechanisms, Crakow 2014, pp. 21-31.

5. http://www.ukrstat.gov.ua/ 
6. Kalinichenko A., Minkova O., Kalinichenko O., Development of ukrainian organic products sector in the international context. J. Socio-Economic problem and the State [online], 2015, Vol. 13, No. 2, pp. 68-75.

7. Kościelniak H., Analysis of the Cost of Capital, Processes of Capital Supply in Production Enterprises. Joint Work Edited by Helena Kościelniak. Prace Wydziału Zarządzania Politechniki Częstochowskiej Serie Monographs No 1., 2006, pp. 61-63.

8. Meskon M., Al'bert M., Khedoury F., Osnovy menedzhmenta [Fundamentals of Management]. Per. s anhl. - M.: Delo, 1998, p. 800.

9. Nogalski B., Waśniewski J., Dryl T., Brand of a product and knowledge about its producer as factors determining consumers trust in brand, [in:] Managing organizations in changing environment. Cracow 2014, pp. 279-290.

10. Nowodziński P., Choosen Issues Affecting Company's Strategy in Competitive Environment. Theoretical Findings., Managing a Business - Strategic Management. Monograph. Ed. Dejan Erić, Helena Kościelniak, Paweł Nowodziński, Institute of Economic Sciences, Belgrade, 2011, pp. 179-190.

11. Romanowska M., Gierszewska M., Strategic analysis in the enterprise. PWE Warsaw 2009.

12. Skowron-Grabowska B., Costs in the Financial Strategies of the Enterprises, [in:] Processes of Capital Supply in Production Enterprises. Joint Work Edited by Helena Kościelniak. Prace Wydziału Zarządzania Politechniki Częstochowskiej Serie Monographs No 1., Czestochowa 2006, pp.77-82.

13. Закон України «Про захист економічної конкуренції» № 2210-III від 11.01.2001 [Електронний ресурс] - Режим доступу: http://zakon4.rada.gov.ua/laws/show/2210-14.

14. Ігнатьєва I.А., Діагностування виробничих систем на основі встановлення пріоритетності стратегічних ичілей // ВІСНИК КНУТД, 2004. - № 6, pp. 135-140.

15. Ігнатьєва I.А., Проблеми очінки конкурентних позицій промислових підприємств // Економика: проблемы теории и практики. - 2005. - № 205, pp. 1129-1140. (0,5 д.а.).

16. Маршалл А., Принциипы экономической науки. - М, 1993. В 3-х т. - Т. 1.

17. Портер М., Конкуренциия: Пер. с англ. - М.: Издательский дом "Вильямс", 2002, p. 496.

18. Портер М., Международная конкуренция: конкурентные преимущества стран. - Пер. с англ. - М.: Международные отношения, 1993, p. 896 с.

19. Соколенко С.И., О кластеризации в странах ОЧЭС. - Деловой вестник - № 12(163), 2007, p. 21.

20. Экономическая стратегия фирмы: Учеб. пособие /Под ред. А.П. Градова. - 3-е изд., испр. - СПб.: Спец-Лит, 2000, р. 588.

21. Юданов А.Ю., Конкуренция: теория и практика: Учебно-практическое пособие. - 2-е изд.- М.: Ассоц. авторов и издателей «Тандем»; ГНОМ-ПРЕСС, 1998. - 384 с.

\section{ANALIZA SYSTEMU ZARZĄDZANIA KONKURENCYJNOŚCIĄ PRZEDSIĘBIORSTW SPOŻYWCZYCH W RÓŻNYCH KANAŁACH DYSTRYBUCJI NA PRZYKŁADZIE UKRAINY}

Streszczenie: W opracowaniu przedstawiono koncepcję konkurencyjności i zarządzania nią w przedsiębiorstwach spożywczych, jak również warunki wstępne utworzenia regionalnych stowarzyszeń branżowych przemysłu spożywczego, jako sposobu na zwiększenie konkurencyjności branży.

Słowa kluczowe: konkurencyjność, stowarzyszenia regionalne, branża spożywcza, kompleks rolniczo przemysłowy, zarządzanie strategiczne, kanał krajowy i dystrybucji 